\title{
Phenology of high-elevation pelagic bacteria: the roles of meteorologic variability, catchment inputs and thermal stratification in structuring communities
}

\author{
Craig E Nelson \\ Marine Science Institute, University of California, Santa Barbara, CA, USA
}

\begin{abstract}
Many eukaryotic communities exhibit predictable seasonality in species composition, but such phenological patterns are not well-documented in bacterial communities. This study quantified seasonal variation in the community composition of bacterioplankton in a high-elevation lake in the Sierra Nevada of California over a 3-year period of 2004-2006. Bacterioplankton exhibited consistent phenological patterns, with distinct, interannually recurring community types characteristic of the spring snowmelt, ice-off and fall-overturn periods in the lake. Thermal stratification was associated with the emergence of specific communities each summer and increased community heterogeneity throughout the water column. Two key environmental variables modulated by regional meteorologic variation, lake residence time and thermal stability, predicted the timing of occurrence of community types each year with $75 \%$ accuracy, and each corresponded with different aspects of variation in community composition (orthogonal ordination axes). Seasonal variation in dissolved organic matter source was characterized fluorometrically in 2005 and was highly correlated with overall variation in bacterial community structure $\left(r_{\text {Mantel }}=0.75, P<0.001\right)$ and with the relative contributions of specific phylotypes within the Cyanobacteria, Actinobacteria and $\beta$-Proteobacteria. The seasonal dynamics of bacterial clades (tracked through coupling of randomized clone sequence libraries to restriction fragment length polymorphism fingerprints) matched previous results from alpine lakes and were variously related to solute inputs, thermal stability and temperature. Taken together, these results describe a phenology of high-elevation bacterioplankton communities linked to climatedriven physical and chemical lake characteristics already known to regulate eukaryotic plankton community structure.
\end{abstract}

The ISME Journal (2009) 3, 13-30; doi:10.1038/ismej.2008.81; published online 11 September 2008

Subject Category: microbial population and community ecology

Keywords: bacterioplankton; community structure; fluorometry; TRFLP; dissolved organic matter; residence time

\section{Introduction}

Predicting the impacts of environmental change on ecosystem processes requires a theoretical and practical understanding of relationships among the structure of ecological communities, ecosystem processes and the abiotic environment. Prokaryotes and other microorganisms have an important function in many fundamental biogeochemical processes (Fuhrman et al., 1989; Conrad, 1996; Cotner and Biddanda, 2002), and microbial community structure is linked to the rates and dynamics of these processes (Cottrell and Kirchman, 2000; Covert and

Correspondence: CE Nelson, Marine Science Institute, University of California, Santa Barbara, CA 93106-9610, USA.

E-mail: cr_nelson@lifesci.ucsb.edu

Received 19 May 2008; revised 28 July 2008; accepted 28 July 2008; published online 11 September 2008
Moran, 2001; Carlson et al., 2002). Ecological theory guides research into the relationships between community structure and function, but the overwhelming genotypic and phenotypic diversity of microorganisms in natural environments confounds efforts to ascribe macroorganismal concepts of community assembly to the microbial world (Finlay, 2002; Prosser et al., 2007).

Phenology, the timing of periodic biological phenomena generally linked to abiotic or climatic factors, is a trait characteristic of many natural communities. Although seasonal changes in environmental factors are likely to generate predictable seasonality in microbial community structure, there have been few studies examining the nature and drivers of microbial phenology. Furthermore, anthropogenic changes in climate and land use may alter seasonal changes in abiotic conditions and microbial communities with consequences for 
biodiversity and ecosystem function, making an understanding of microbial phenology relevant to the evaluation of human impacts on ecosystems (Chapin et al., 2000; Walther et al., 2002).

The enormous diversity, small size, large populations, rapid generation times, high probability of dispersal, functional redundancy and genomic/ phenotypic plasticity of bacteria can produce a remarkable degree of intra- and interannual variability in community composition (Ochman et al., 2000; Curtis and Sloan, 2004). Most studies that have examined the seasonal dynamics of prokaryotic communities have reported significant temporal trajectories across seasons, but incomplete or inconsistent interannual cycles (Lindstrom, 1998; Crump et al., 2003; Stepanauskas et al., 2003; Yannarell et al., 2003; Kent et al., 2004). Perhaps unsurprisingly, recent efforts to quantify synchronous temporal variation in spatially segregated microbial communities from similar environments have met with some success, likely due, in part, to the homogenization of regional climatic variability among study sites (Crump and Hobbie, 2005; Kent et al., 2007). A suite of more recent studies of lake, stream, estuarine, coastal and open ocean environments has shown recurring interannual patterns in bacterioplankton community structure by relying on high-frequency, multi-year data sets (Morris et al., 2005; Fuhrman et al., 2006; Hullar et al., 2006; Kan et al., 2006; Shade et al., 2007).

Examining the temporal dynamics of bacterial community composition in isolated resource-poor environments with strong seasonality can limit many of the potential sources of variability in prokaryotic community structure, allowing a clear and detailed understanding of microbial phenology. High-elevation lakes are ideal systems for this approach because they are well-constrained, dilute, unproductive environments remote from human influence. In addition, these systems have large and relatively predictable seasonal variations in nutrient availability, primary production, external inputs and physical properties (Melack et al., 1997). High-elevation and high-latitude ecosystems are recognized as early-warning systems for detecting ecological responses to global environmental changes because of their sensitivity to anthropogenic disturbance and regional climatic shifts (Beniston et al., 1997; Melack et al., 1997; Carrera et al., 2002; Fenn et al., 2003; Sickman et al., 2003b; Morales-Baquero et al., 2006b). Montane lakes worldwide have become increasingly affected by the atmospheric deposition of nutrients and pollutants (Psenner, 1999), factors that directly influence the metabolism and community structure of bacteria (Cotner et al., 1997; Carlson et al., 2002; Haukka et al., 2006). Biogeochemical and food web processes in oligotrophic aquatic environments such as these are predicted to be dominated by microbial metabolism (Biddanda et al., 2001), indicating that understanding the role of prokaryotes in these environments is relevant to predicting system-level ecological responses to environmental change. Finally, high-elevation and high-latitude systems display large temporal changes in the source and composition of dissolved organic matter, a fundamental link between ecosystem function and the community structure of heterotrophic bacteria, making them ideal systems in which to examine this key relationship (Crump et al., 2003; Hood et al., 2003; Judd et al., 2006; Perez and Sommaruga, 2006).

The study detailed here examined bacterial community composition over a 3-year period throughout the water column of a high-elevation cirque lake in the Sierra Nevada of California (USA). PCR-based community fingerprinting methods were combined with the construction of multiple randomized clonesequence libraries to provide estimates of the relative abundance of specific bacterial phylotypes through time and space, as well as to relate bacterial community composition to a variety of measured physical and biogeochemical variables. The results demonstrate a predictable phenology of bacterial community structure in Emerald Lake related to lake physical and chemical parameters. Clone library analysis permitted estimation of the diversity of, and phylogenetic differences in, the bacterial community across seasons. The temporal dynamics of bacterial community structure were linked to interannual variation in weather as well as seasonal transitions in catchment inputs and lake thermal structure, supporting evidence for fundamental linkages among organic matter composition, nutrient availability, climatic forcing and the structure of bacterial communities.

\section{Materials and methods}

\section{Research location}

This research was conducted at Emerald Lake, a headwater cirque lake located within Sequoia National Park on the western slope of the south central Sierra Nevada (California, CA, USA, $\left.36^{\circ} 35^{\prime} 49^{\prime \prime} \mathrm{N}, 118^{\circ} 40^{\prime} 30^{\prime \prime} \mathrm{W}\right)$. The lake, situated at $2800 \mathrm{~m}$ above sea level in a sparsely forested granitic catchment, is representative of the $>4000$ highelevation ( $>2500 \mathrm{~m}$ above sea level) lakes scattered throughout the Sierra Nevada in size (2.7 ha, $10.5 \mathrm{~m}$ $\left.Z_{\max }\right)$, solute chemistry and catchment composition (median slope $31 \%$; surface area $75 \%$ exposed granitic and granodioritic rock, 19\% montane meadow, 3\% sparse conifer, 3\% water; Melack and Stoddard, 1991). The lake has been studied for several decades, and its hydrology, biogeochemistry and ecology are well characterized (Sickman et al., 2003b). Emerald Lake is remote, accessible only by an $8 \mathrm{~km}$ hike (with $1 \mathrm{~km}$ elevation gain) from the nearest road. The lake has a single main inlet and several smaller inlets all of which carry terrestrial runoff. Emerald Lake is dimictic and typically snow- 
covered from November to June, with the timing of ice-off ranging from mid-May to late July depending on the size of the snowpack and the timing of spring thaw. Spring mixing is brief, lasting about a week following ice-off, whereas fall mixing may continue for up to 2 months before the lake ices over. Metalimnetic temperatures range from 4 to $15^{\circ} \mathrm{C}$ and epilimnetic temperatures range from 0 to $22^{\circ} \mathrm{C}$. During summer stratification, the metalimnion and thermocline generally begin between 4 and $7 \mathrm{~m}$ depth and extend to the bottom of the lake. Snowmelt flushing of nitrate is characteristic of catchments in the Sierra Nevada (Sickman et al., 2003a), and concentrations within Emerald Lake may range over two orders of magnitude $\left(0.1-10 \mu \mathrm{mol} \mathrm{l}^{-1}\right)$ throughout the growing season as snowmelt progresses.

\section{Sample collection and processing}

The lake was sampled approximately biweekly throughout the ice-free periods of 2004 and 2005 and three times in 2006. Several samples were collected midwinter 2004-2005 and during the icecovered snowmelt period in 2005 and 2006. Midday on each sampling date I collected 3-6 l of water for chemical analyses from four depths in the center of the lake and from the inlet through a hand-cranked peristaltic pump through platinum-cured silicone tubing into collapsible $10 \mathrm{l}$ low-density polyethylene carboys (Reliance Products 250013). Samples collected and parameters measured included the following: particulate carbon, nitrogen and reactive phosphorus; total dissolved nitrogen (TDN) and phosphorus; dissolved organic carbon (DOC); dissolved inorganic nitrate/nitrite (DIN); soluble reactive phosphorus (SRP); dissolved fluorescence (fluorescence index (FI), detailed below); and concentrations of chlorophyll a. I collected an additional water sample from each depth and location in polycarbonate bottles for DNA analysis. Samples were filtered and preserved on site and stored in the dark at ambient temperature $\left(<15^{\circ} \mathrm{C}\right)$ for $24 \mathrm{~h}$ during transport to cold storage facilities. All plasticware were acid-washed and rinsed between sampling events and triple-rinsed with sample water before collection.

I collected particulates by gentle in-line gravity filtration of $\sim 450 \mathrm{ml}$ of sample water onto combusted $\left(2 \mathrm{~h}, 450^{\circ} \mathrm{C}\right) 47-\mathrm{mm}$ Whatman GF/F filters (nominal pore size $0.7 \mu \mathrm{m}$ ) held in polycarbonate filter cartridges. One filter was used for chlorophyll analysis, a second for particulate carbon and particulate nitrogen, and a third for particulate reactive phosphorus, each folded closed, wrapped in combusted aluminium foil and frozen $\left(-20^{\circ} \mathrm{C}\right)$ upon return to the laboratory. Dissolved nutrients (TDN, total dissolved phosphorus, DIN and SRP) were analyzed from GF/F filtrate collected in new sample-rinsed HDPE bottles (Nalgene brand, Thermo Fisher Scientific, Rochester, NY, USA). DOC and dissolved fluorescence were analyzed from GF/F filtrate collected in acid-washed, combusted $(12 \mathrm{~h}$ at $450{ }^{\circ} \mathrm{C}$ ), amber glass EPA vials (I-Chem brand, Thermo Fisher Scientific, Rochester, NY, USA) with Teflon-coated septa immediately amended with concentrated acid (to $\sim 20 \mu \mathrm{moll}^{-1} \mathrm{HCl}$ ) and stored frozen $\left(-20^{\circ} \mathrm{C}\right)$ upon return to the laboratory. I collected DNA samples by filtering $\sim 400 \mathrm{ml}$ of whole water sample onto a $0.22-\mu \mathrm{m}$ pore size polyethersulfone filter cartridge (Millipore Sterivex SVGP01050). After filtering, the cartridge was immediately emptied of excess water, filled with sucrose lysis buffer $\left(40 \mathrm{mmol} \mathrm{l}^{-1}\right.$ EDTA, $50 \mathrm{mmol} \mathrm{l}^{-1}$ Tris-HCl, $750 \mathrm{mmol}^{-1}$ sucrose, $\mathrm{pH}$ adjusted to 8.0), sealed with parafilm, stored at an ambient temperature overnight and frozen $\left(-80^{\circ} \mathrm{C}\right)$ on return to the laboratory (tests comparing terminal restriction fragment length polymorphism (TRFLP) fingerprints between samples immediately frozen and those held at an ambient temperature for 1-4 days were not significantly different and exhibited Sorensen distances of $<0.05$ ).

At each sampling time, I measured vertical profiles of dissolved oxygen and temperature at $50 \mathrm{~cm}$ intervals with an elevation-calibrated, batteryoperated, handheld meter (YSI 55). Magnitude and temperature of discharge from the lake were monitored continuously using a calibrated weir and pressure transducer with temperature sensor, and hydraulic residence time on each day was calculated as the number of summed preceding discharge days $\left(\mathrm{m}^{3} \mathrm{~d}^{-1}\right)$ required to equal the lake volume $\left(1.8 \times 10^{5} \mathrm{~m}^{3}\right)$. Lake thermal stability was calculated from thermal profiles according to Schmidt (1928) following the modifications of Idso (1973).

\section{Chemical analytical procedures}

Particulate carbon and particulate nitrogen were analyzed through double-drop GF/F combustion on an organic elemental analyzer (Control Equipment Corporation Model 440HA) by the UCSB Marine Science Institute Analytical Laboratory. I measured concentrations of particulate chlorophyll a by darkdigesting filters for $24-48 \mathrm{~h}$ in $90 \%$ acetone at $-20{ }^{\circ} \mathrm{C}$ followed by $10 \mathrm{~m}$ dark centrifugation and immediate fluorescence analysis on a Turner AU-10 fluorometer (Smith et al., 1981). DIN and SRP were measured by the UCSB Marine Science Institute Analytical Laboratory on a Lachat Instruments Quickchem 8000 flow injection autoanalyzer. TDN and total dissolved phosphorus were measured as DIN and SRP from GF/F filtrate following digestion $(10 \mathrm{ml}$ sample amended with oxidation reagent and autoclaved according to Valderrama, 1981), neutralization with $\mathrm{NaOH}$ and subtraction of digested double-distilled water blanks. Particulate reactive phosphorus was analyzed by digesting GF/F filters in $30 \mathrm{ml}$ double-distilled water amended as for TDN/P above and measuring SRP after filter-blank subtraction to correct for silicate interference. Dissolved organic nitrogen (DON) was calculated 
as the difference between TDN and DIN, and total phosphorus (TP) was calculated as the sum of particulate reactive phosphorus and total dissolved phosphorus. I measured DOC concentrations on a Shimadzu TOC-V adapted to increase precision in the range of $5-100 \mu \mathrm{mol} \mathrm{l}^{-1}$ (Carlson et al., 2004).

Fluorescence index was used to determine seasonal variation in the relative influence of terrestrial and lake-derived sources of dissolved organic matter (DOM) (McKnight et al., 2001). The index was calculated as the ratio of emission intensity at $450 \mathrm{~nm}$ to emission intensity at $500 \mathrm{~nm}$ under excitation at $370 \mathrm{~nm}$ after subtraction of a doubledistilled water water blank measured on a Shimadzu RF-1501 spectrofluorometer in the laboratory of JO Sickman at the University of Florida, Gainesville, FL, USA. This metric estimates the relative contribution of allochthonous (terrestrially derived) and autochthonous (phytoplankton-derived) fulvic acids to the dissolved organic pool of surface waters and has been employed successfully in high-elevation lakes and streams in the Rocky Mountains, USA (Hood et al., 2003).

\section{Bacterial community fingerprinting}

TRFLP was used as a fingerprinting method for comparison of bacterial community composition among DNA samples (Liu et al., 1997). Sterivex capsules were thawed and amended with proteinase $\mathrm{K}\left(0.2 \mathrm{mg} \mathrm{ml}^{-1}\right)$, sodium dodecyl sulfate $(1 \% \mathrm{w} / \mathrm{v})$ and lysozyme $\left(0.5 \mathrm{mg} \mathrm{ml}^{-1}\right)$ at $37^{\circ} \mathrm{C}$ for $30 \mathrm{~min}$ followed by $55{ }^{\circ} \mathrm{C}$ for $2-12 \mathrm{~h}$ and extracted immediately. Genomic DNA extraction was performed using Qiagen DNEasy centrifuge columns. Extracted DNA was amplified by PCR as follows: a reaction mix consisting of $2.5 \mathrm{mmol} \mathrm{l}^{-1} \mathrm{MgCl}_{2}, 200 \mu \mathrm{mol} \mathrm{l}^{-1} \mathrm{dNTP}$ mix, 5\% Acetamide, $4-14 \%$ template ( $\sim 10 \mathrm{ng}$ ), $10 \mu \mathrm{l}$ mineral oil, $1 \mathrm{U}$ Taq DNA Polymerase in buffer and $200 \mathrm{nmoll}^{-1}$ each of primers 27F (AGAGTTTGATCMTGGCT, FAM-labeled) and 519R (GWATTACCGCGGCKGCTG, unlabeled) was subjected to thermocycling consisting of $3 \mathrm{~min}$ initial denaturation at $94{ }^{\circ} \mathrm{C}, 30$ cycles of $1 \mathrm{~min} 94^{\circ} \mathrm{C}$ denaturation followed by $1 \mathrm{~min} 58^{\circ} \mathrm{C}$ annealing followed by $2 \mathrm{~min}$ $72{ }^{\circ} \mathrm{C}$ extension and $10 \mathrm{~min}$ final extension at $72{ }^{\circ} \mathrm{C}$ before being held at $4{ }^{\circ} \mathrm{C}$ until further processing. PCR products were cleansed of small-fragment DNA using the Qiagen QiaQuick DNA Cleanup Kit and then digested for $4 \mathrm{~h}$ at $37^{\circ} \mathrm{C}$ with restriction enzyme HaeIII (New England Biolabs, Ipswich, MA, USA) followed by 20 min enzyme inactivation at $80^{\circ} \mathrm{C}$ and storage at $4{ }^{\circ} \mathrm{C}$.

Digested products were analyzed on an Applied Biosystems ABI 310 sequencer using GeneScan Software. A size standard (MapMarker 1000) was run with every sample to define the standard curve between 25 and $600 \mathrm{bp}$, and the Global Southern curve-fitting algorithm was used to calculate bp lengths of identified fluorescence peaks. The peak identification cutoff for relative fluorescence units (rfu) was typically $50 \mathrm{rfu}$, the minimum peak halfwidth was three data points and the typical range of quantified peaks was 300-3000 rfu. Samples were completely reprocessed if the bulk of the peaks in the electropherogram were below $500 \mathrm{rfu}$.

Terminal restriction fragment length polymorphism data from all samples were aligned using a novel frequency-based alignment method. This method avoids the inaccuracies associated with common approaches to 'binning' fragment lengths using integer rounding or truncation methods (Figure 1, see also Hewson and Fuhrman, 2006). In RFLP analyses, GeneScan fragment lengths are calculated using size calculation algorithms derived from simultaneous electrophoresis of a size standard and do not exhibit consistent rounded integer lengths either in theory or in practice. The frequency-based alignment method employed here relies on comparison of samples among a large environmental data set to identify and group electropherogram peaks based on frequency distributions among samples (Figure 1). Briefly, fragmentlength data from the entire data set were pooled and sorted by length. Fragments within the length ranges where multiple samples exhibit dominant electrophoretic fluorescence peaks were assigned integer lengths based on the mean and variance of each group and the size of the gap between regions of higher sample density. Distributional gaps between named groups, which differ by $<1 \mathrm{bp}$, were further delineated using samples that contain both fragments under the assumption that individual samples are unlikely to display two peaks $1 \mathrm{bp}$ apart if only one fragment is present (the phenomenon of 'shouldering' rarely extends a full 1-bp distance). In the case of the present data set, fragments were defined by delineating frequency distributions by 0.05 bp gaps from a data set of all peaks comprising $>1 \%$ total within-sample electropherogram area (Figure 1). Smaller peaks of $0.5 \%$ or greater sample electropherogram area, which fell within 1 s.d. of a group mean, were added post facto.

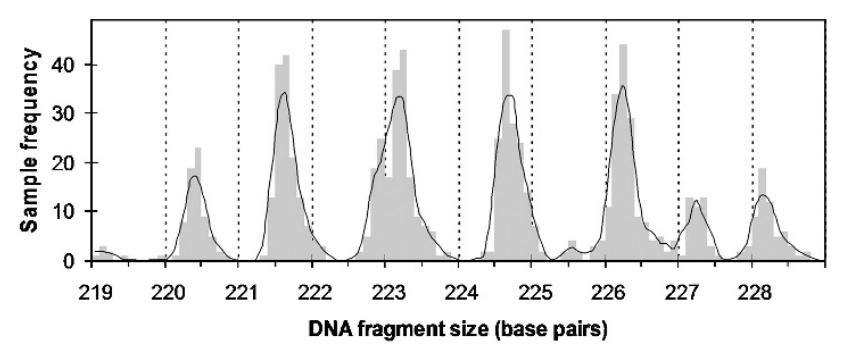

Figure 1 Frequency histogram of representative GeneScancalculated fragment lengths derived from TRFLP analysis of $16 \mathrm{~S}$ rDNA collected from Emerald Lake, 2004-2006. The line is a three-point moving average. Note that binning fragments through integer rounding or truncation (integers denoted by dashed lines) will produce innaccurate groupings, whereas the binning method employed in this study can clearly group similar fragments into phylotypes using frequency distributions derived from comparing samples within a larger data set. TRFLP, terminal restriction fragment length polymorphism. 
Bacterial clone library construction

To ascribe terminal restriction fragment lengths to specific bacterial phylotypes, five clone libraries (96 clones each) were constructed from environmental samples drawn from the lake in 2005. Libraries were randomly generated from 2-m depth samples on three dates (6 June 2005, 31 July 2005 and 18 September 2005) to capture the three interannually recurring TRFLP community types, and one library was generated from the inlet on 6 June 2005 . Duplicate libraries were generated by separate cloning procedures from the $2-m$ depth DNA sample on 31 July 2005 to allow statistical reference comparison of identical libraries (see Supplementary Information).

DNA from these environmental samples was extracted using identical methods as above and duplicate $100 \mu \mathrm{l}$ PCRs were carried out as above except without an FAM tag on the 27F primer. PCR products were concentrated twofold using QiaQuick columns, then gel-extracted and further concentrated to $30 \mu \mathrm{l}$ with a second QiaQuick column. PCR products were then ligated into the pGEM-t plasmid cloning vector (Promega, Madison, WI, USA) and transformed into competent Escherichia coli DH5 $\alpha$ according to the vendor's guidelines. Transformants were plated onto LB/Amp $\left(100 \mu \mathrm{g} \mathrm{ml}^{-1}\right) / \mathrm{X}-\mathrm{Gal} / \mathrm{IPTG}$ plates, randomly selected for sequencing by white/ blue screening, and sequenced by unidirectional rolling-circle PCR by the University of Washington High Throughput Sequencing Facility.

Sequences were collated and trimmed to the primer region using the BioEdit program (Hall, 1999), aligned using the NAST aligner (DeSantis et al., 2006a), classified using maximum likelihood algorithms to the GreenGenes 16S rDNA database (DeSantis et al., 2006b) and checked for chimeras using Bellerophon 1.3 (Huber et al., 2004). Putative chimeras and sequences classified as plastids were excluded from further analyses, the library was dereplicated into unique phylotypes using FASTGROUPII (Yu et al., 2006) at a level of 97 percent sequence identity, and the remaining sequences were digested in silico using the Sequence Manipulation Suite software (Stothard, 2000).

As in silico TRF lengths frequently differ from measured GeneScan TRF links because of minor instrument and PCR error (Morris et al., 2005), a subset of 25 clones representing unique in silico restriction lengths was analyzed by TRFLP (as above except plasmid DNA was extracted using Qiagen Miniprep columns rather than DNEasy) using the duplicate pooling approach detailed by Grant and Ogilvie (2004). A linear regression ((GeneScan bp length) $=1.018$ (in silico bp length)-7.583; $r^{2}=0.99$; range $39-517 \mathrm{bp)}$ was used to correct GeneScan-estimated TRF lengths from experimental samples and representative clones were ascribed to each matching TRF length (Stepanauskas et al., 2003; Brown et al., 2005; Morris et al., 2005).
Data analysis

Bacterial community composition data for all TRFLP samples were collated using relative abundance data (estimated as within-sample relativized eletropherogram peak area for each fragment; Yannarell and Triplett, 2005) after removal of all the fragments less than $150 \mathrm{bp}$ (due to size-calling algorithm inaccuracies associated with smaller fragment lengths). Multivariate community distances were calculated as the Sørenson dissimilarity index (aka Bray-Curtis or Percent Dissimilarity, calculated $1-(2 W /(A+B))$ where $W$ is the sum of shared relative abundances) $A$ and $B$ are the sums of relative abundances in individual sample units; (Sørensen, 1948)) using PC-ORD software (McCune and Mefford, 2006). Samples were clustered using the flexible- $\beta$ algorithm (Figure $2 ; \beta=-0.25$ ) in PCORD and divided into groups using a distance cutoff selected to minimize number of groups, minimize within-group distances and maximize variance explained (estimated using the 'elbow criteria' in a graph relating variance explained to the number of groups). Nonmetric multidimensional scaling (NMS) was employed to ordinate data in a lower dimensional space using PC-ORD software. The ordination was forced to a two-dimensional solution to enhance interpretability, and bacterial community data from terrestrial inlet samples were excluded from the ordination because their relatively high dissimilarity from lake samples across years concealed variability among lake samples.

A phylogenetic tree was constructed from the pooled clone library sequences to characterize the taxonomic relatedness of bacterioplankton across seasons. Aligned sequences of the three most similar cultured and uncultured sequences to each Emerald Lake clone and in the GreenGenes prokMSA database (along with a single Archaeal outgroup sequence) were combined into a complete alignment (800 sequences altogether, 351 clones and 449 GenBank/prokMSA sequences) to allow parsimonious tree construction in the context of existing phylogenies. DNADist and NEIGHBOR algorithms in the software package PHYLIP (Felsenstein, 2005) were used to generate a neighbor-joining tree from a distance matrix of the aligned sequences and the resulting tree was uploaded to the Interactive Tree of Life (Letunic and Bork, 2007) and pruned to remove sequences not derived from Emerald Lake samples. Nodes were assigned taxonomic clade identities when possible based on the lowest defined classification level of the sequences within a cluster displaying a maximum likelihood similarity of $>0.85$ to classified GreenGenes prokMSA sequences (Hugenholtz taxonomy).

Relationships between bacterial community structure and environmental measurements were examined using both linear and multivariate modeling approaches. All environmental measurements and relative abundance data for individual bacterial phylotypes were transformed to meet the 


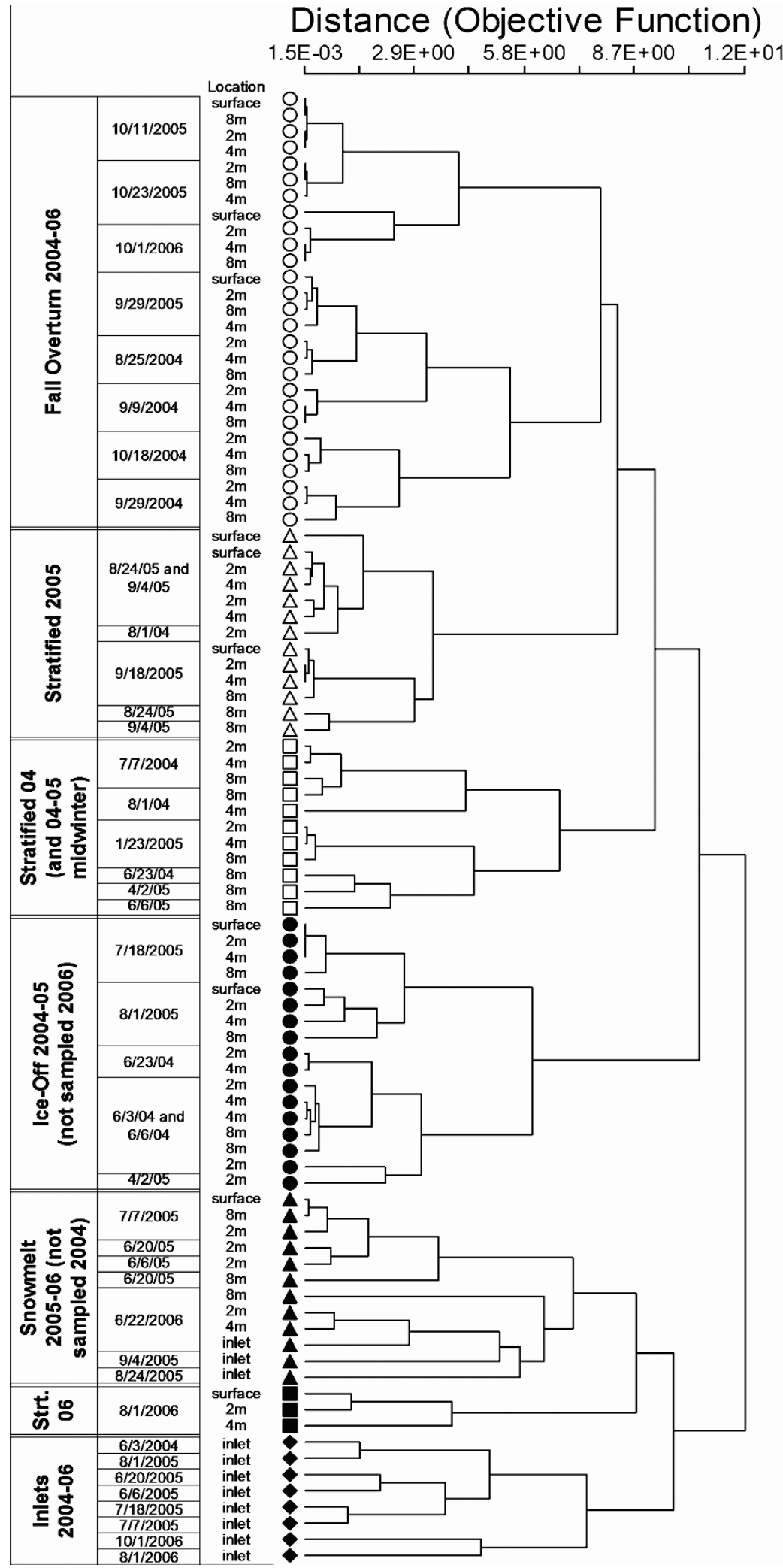

Figure 2 Cluster dendrogram of TRFLP fingerprint data from DNA samples collected from Emerald Lake and its inlet, 2004-2006. The dendrogram was constructed from Sørensen distances between TRFLP samples clustered using the flexible- $\beta$ method ( $\beta=-0.25)$ and scaled according to Wishart's objective function. Samples are coded by seven groups selected to minimize within-group distances and maximize the proportion of the overall variance explained in the data set. Groups are named according to similarity between samples with respect to lake mixing status. All groups are significantly different according to the Multiresponse Permutation Procedure (MRPP; McCune and Mefford (2006): $A=0.28$, all pairwise $P \ll 0.001$, within-group Sørensen dissimilarity $<50$ except inlets $=0.62$ ). TRFLP, terminal restriction fragment length polymorphism. 
assumptions of parametric statistical analyses (JMP V.7; SAS-Institute, 2007). Twenty lake samples were excluded from multivariate environmental analyses (final $n=60$ ) because of incomplete environmental characterization: January and April (midwinter) 2005 (five samples), third and sixth June 2004 (six samples), and all of 2006 (nine samples). Relationships between NMS ordination axes of bacterial community structure and environmental variables were assessed using least squares linear regression analyses. Forward stepwise multiple regression was used to examine relationships between environmental variables and the relative abundances of summed fragments within clades as follows: environmental variables were added to the model sequentially and additive increases in the coefficient of determination were examined, with nonsignificant variables being dropped from the final model. One-way analysis of variance and Tukey multiple comparisons tests were used to evaluate if various environmental or phylotype variables differed significantly among TRFLP clusters defined in Figure 2. Stepwise discriminant function analysis (a form of multivariate analysis of variance) was used to evaluate which independent variables (environmental parameters or sequence-based phylotypes) have significantly different means among TRFLP clusters and can successfully discriminate between the cluster groupings. Finally, the BIO-ENV routine was employed in PRIMER-E software v5 (Clarke and Ainsworth, 1993) to identify the environmental and biogeochemical variables most highly correlated with TRFLP variation between samples. This routine generates Euclidean distance matrices of samples based on environmental variables individually or in combination and tests the correlation between each matrix and the Sørensen dissimilarity matrix of bacterial community composition generated from the TRFLP fingerprint data (analogous to the Mantel test).

\section{Results}

Interannual variation in lake properties

The sampling period, 2004-2006, spanned a wide range of regional meteorologic patterns, with 2004 being a relatively dry year and both 2005 and 2006 exhibiting near-record winter precipitation and snowpack duration (Figure 3). Peak snowmelt discharge in 2004 was $<10000 \mathrm{~m}^{3} \mathrm{~d}^{-1}$, snowmelt extended from late April to mid-June and the ice cover on the lake melted in late May. In contrast, 2005 and 2006 both exhibited peak discharge values $>40000 \mathrm{~m}^{3} \mathrm{~d}^{-1}$, with snowmelt extending from mid-May to late August and the lake remaining fully ice-covered until mid-July. The duration and magnitude of summer stratification (measured as thermal stability) were larger in 2004 than in 2005 and 2006, and the length of the growing season was considerably curtailed in the latter years. Average integrated stocks of both dissolved and particulate organic carbon in 2004 were nearly double those of 2005 and 2006, and rates of primary production and concentrations of chlorophyll a were higher on average in 2004 than in the latter 2 years (data not shown). A steady decline in lake nitrate concentrations throughout the summer period with declining snowmelt inputs was consistent in all 3 years as has been observed previously in many high-elevation environments (for example, Sickman et al., 2003a).

Temporal patterns in bacterial community structure Seven distinct bacterial community types were defined from multivariate clustering of samples according to similarity in TRFLP fingerprints (Figure 2). Inflowing terrestrial runoff communities were distinct from lake communities across all 3 years, although during snowmelt periods, inlet communities were more similar to lake communities than at other times of the year (Figures 2 and 3). Lake communities were more similar within sampling dates than between dates when the water column was well mixed (Figure 3), but community distance throughout the water column on a given date was positively related to both water-column distance and degree of stratification (Figure 4). During strongly stratified periods, epilimnetic and hypolimnetic communities were sufficiently distinct to be grouped as separate community types, with hypolimnetic communities generally grouping with samples from the previous sampling date (Figure 3).

Three of the six lake community types were observed to recur in multiple samples across years, whereas the remaining types were specific for a given year and observed only during stratified periods (Figures 2 and 3). Communities were most similar interannually during fall following convective overturn across all 3 years (Fall Overturn Group). Lake communities during peak snowmelt periods (before ice-off) were similar in 2005 and 2006 (Snowmelt Group; this period was not sampled in 2004) as were lake communities found during early stratification following ice-off in 2004 and 2005 (Ice-Off Group-this period was not sampled in 2006; Figures 2 and 3). Lake community types differed significantly in mean ordinal date, residence time and thermal stability, and discriminant analysis using residence time and thermal stability alone successfully delineated bacterial community type for $75 \%$ of the samples (Table 1 ).

\section{Correlation between community structure and environmental parameters}

Bacterial rDNA samples were ordinated into two dimensions by NMS of TRFLP community similarity (Figure 5c), with lake thermal stability and hydraulic residence time strongly correlated 


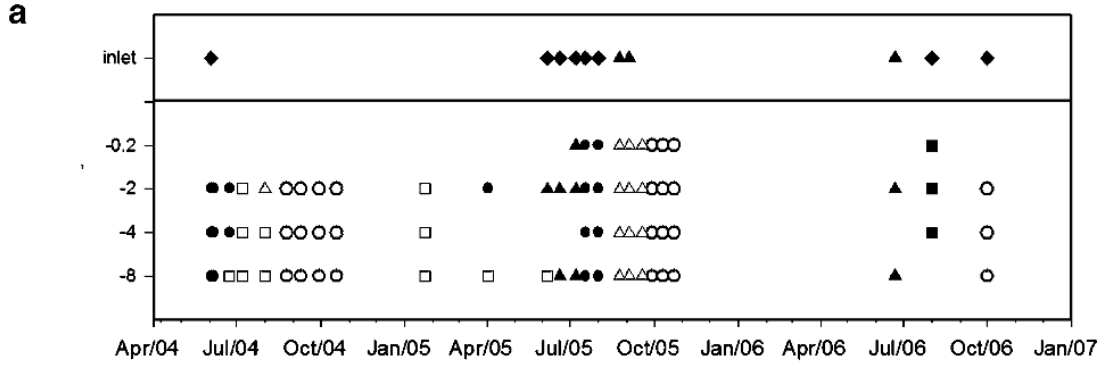

b

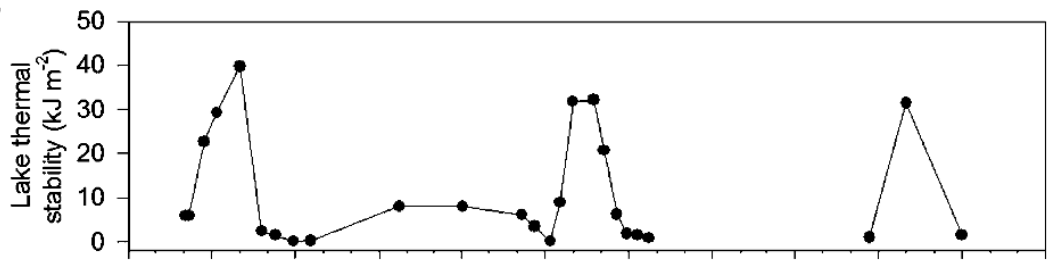

C
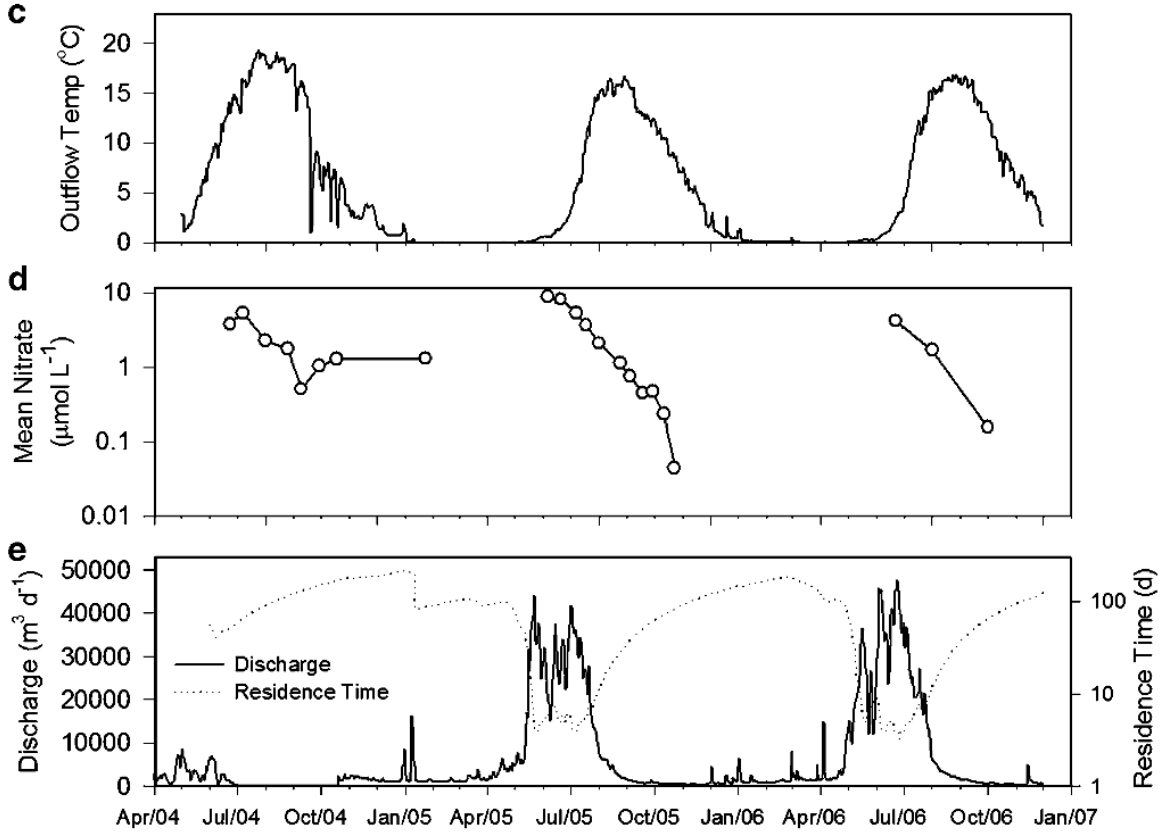

Figure 3 Bacterial community types and values of physical variables in Emerald Lake, 2004-2006. (a) shows the distribution of TRFLP community fingerprint types (defined in Figure 1) through time at different depths in the water column as well as the inlet stream. (b) shows the thermal stability of the lake at each sampling time based on temperature profiles. (c) shows the temperature in the outflow stream. (d) shows depth-averaged water-column nitrate concentration and (e) displays the discharge in the outlet stream, as measured using a pressure transducer at the outlet weir and calculated theoretical lake hydraulic residence time. TRFLP, terminal restriction fragment length polymorphism.

with the respective NMS axes (Figures $5 \mathrm{~b}$ and d). Although measured only in 2005, the DOM FI was strongly related to NMS Axis 2 and was more strongly correlated with NMS axis values than any other variable in that year (Figure 5a). Additional variables significantly related to NMS axes scores across the 3-year data set were temperature, nitrate, particulate carbon, particulate nitrogen, DOC, DON and chlorophyll a $(P<0.01$, $\left.r^{2}=0.15-0.27\right)$. Correlations between TRFLP Sørensen distances and environmental distances using the BIO-ENV algorithm supported the strong correlation between community structure and hydraulic residence time $\left(r_{\text {Mantel }}=0.64\right)$, with the addition of thermal stability, temperature, nitrate and DON marginally strengthening the relationship ( $r_{\text {Mantel }}=0.73$ between TRFLP community distance and a Euclidean distance matrix generated from all five parameters; Table 2). In 2005, a distance matrix generated from DOM FI values alone had nearly as strong a correlation to TRFLP community distance as did the environmental distance matrix generated from the five variables used in the final model outlined above (Table $2 ; r_{\text {Mantel }}=0.75$ and 0.81 for correlation between TRFLP distances and matrices generated either from FI or from the five variables, respectively, using only 2005 data). 
Temporal dynamics and environmental correlates of bacterial phylotypes

To better understand seasonal dynamics of specific bacterioplankton taxa, I calculated relative abundances for each of the eight dominant bacterial clades by summing the relative areas of TRFLP peaks belonging to a given clade (Figure 6 and Supplementary Information). Most clades were

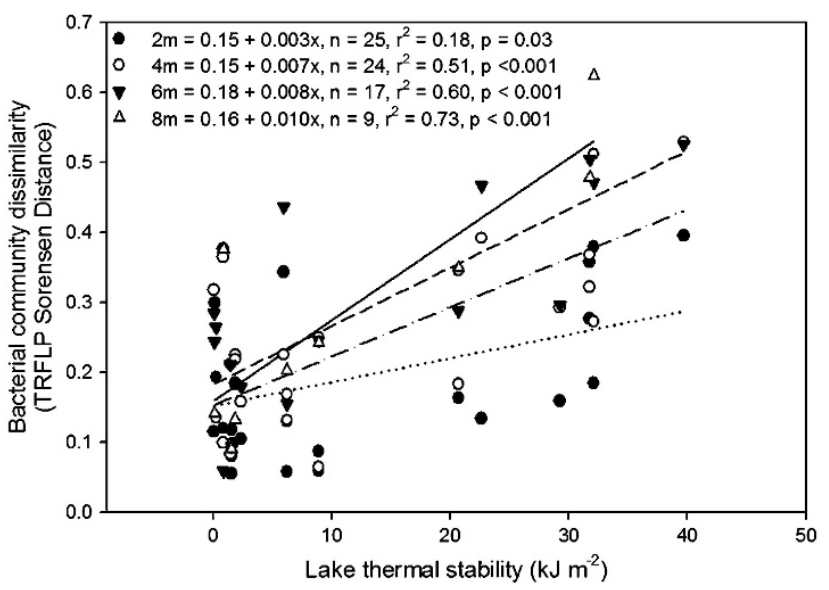

Figure 4 Relationship between lake thermal stability and bacterial community dissimilarity (measured as the Sorensen distance between TRFLP samples) for pairs of samples separated by given water-column distances (depth differences). Each data point represents the community distance between two samples within the water column of Emerald Lake during the ice-free periods of 2004 and 2005 coded by symbols according to the pairwise difference in intersample depth. Specifically, $2 \mathrm{~m}$ distances include the surface: $2 \mathrm{~m}$ and $2: 4 \mathrm{~m}$ sample pairs, $4 \mathrm{~m}$ distance includes the surface: $4 \mathrm{~m}$ and $4: 8 \mathrm{~m}$ pairs, the $6 \mathrm{~m}$ distance is the $2: 8 \mathrm{~m}$ pair and the $8 \mathrm{~m}$ distance is the surface: $8 \mathrm{~m}$ pair for individual sampling dates. Surface samples were collected only in 2005. During stratified periods, the thermocline lies between 4 and $6 \mathrm{~m}$. Note that community dissimilarity increases with an increasing intensity of stratification and the slope of this relationship increases with increased distance (depth differences) between samples in the water column. Community differences in epilimnetic samples $2 \mathrm{~m}$ apart were not related to the intensity of stratification, likely due to diurnal and wind-driven mixing in the epilimnion. TRFLP, terminal restriction fragment length polymorphism. comprised of clones exhibiting one to four TRFLP fragment lengths, although the Burkholderiales group within the $\beta$-Proteobacteria contained 12 fragment lengths (Table 3 and Figure 6). Statistically, variation in the relative abundances of these eight clades dominated total community structure variation, successfully classifying 95\% of TRFLP samples into the community types defined in Figure 2 (Wilk's Lambda, $P<0.0001$ ).

In general, clades were unevenly represented among seasons within the lake, with early-season samples dominated by Flavobacteria and $\beta$-Proteobacteria and late-season samples dominated by Actinobacteria and Sphingobacteria. The proportion of the total relative abundances of fragment lengths contributed by the eight dominant clades was generally higher during the growing season (late July through September), whereas less common phylotypes showed greater representation in the community, resulting in higher evenness, during midwinter and snowmelt periods (Table 3, Figure 7). Flavobacteria comprised a larger proportion of the community during ice-off and 2006 stratification and Actinobacteria became dominant during stratified periods. Burkholderiales generally comprised a large proportion of the community in all seasons, whereas Verrucomicrobia were generally a small proportion of the community with modest peaks in relative abundance during ice-off and stratification 2005. The Sphingobacteria and Methylophilales composed a greater proportion of the community during snowmelt and ice-off, with the Sphingobacteria showing another relative abundance peak during fall overturn, whereas the Cyanobacteria showed peak relative abundances during stratification (2005) and fall overturn, periods of peak primary production in the lake (data not shown). The inlet community was dominated by the Microbacteriaceae and Burkholderiales of the Actinobacteria and $\beta$-Proteobacteria.

The DOM FI, which was the environmental variable with the strongest relationship to community structure in 2005 (Table 2), was positively

Table 1 Mean values and results of ANOVA comparing residence time and thermal stability for each lake TRFLP cluster defined in Figure 1

\begin{tabular}{|c|c|c|c|c|c|}
\hline \multirow{2}{*}{$\begin{array}{l}\text { Group } \\
\text { Snowmelt }\end{array}$} & \multirow{2}{*}{$\begin{array}{l}\mathrm{n} \\
9\end{array}$} & \multicolumn{2}{|c|}{ Residence time (d) } & \multicolumn{2}{|c|}{ Thermal stability $\left(\mathrm{kJ} \mathrm{m}^{-2}\right)$} \\
\hline & & 5 & $\mathrm{E}$ & 1.77 & $\mathrm{C}$ \\
\hline Ice-off & 17 & 21 & CD & 14.79 & B \\
\hline Stratified 2004/midwinter 2005 & 11 & 61 & $\mathrm{AB}$ & 20.72 & $\mathrm{AB}$ \\
\hline Stratified 2005 & 13 & 41 & BC & 21.21 & $\mathrm{AB}$ \\
\hline Stratified 2006 & 3 & 12 & $\mathrm{DE}$ & 31.44 & A \\
\hline Overturn & 27 & 96 & $\mathrm{~A}$ & 1.18 & $\mathrm{C}$ \\
\hline ANOVA $r^{2}$ (F ratio) & 80 & \multirow{2}{*}{\multicolumn{2}{|c|}{$\begin{array}{c}0.74(41) \\
1(44)\end{array}$}} & \multicolumn{2}{|c|}{$0.70(35)$} \\
\hline DA step (\# misclassified) & 80 & & & \multicolumn{2}{|c|}{$2(20)$} \\
\hline
\end{tabular}

Abbreviations: ANOVA, analysis of variance; TRFLP, terminal restriction fragment length polymorphism.

Inlets are excluded. Letters denote significant differences using Tukey multiple comparisons test at $P<0.01$. Columns are ordered according to results of stepwise Discriminant Analysis, with residence time the first variable entered and thermal stability the second and the number of misclassified samples $(n=80)$ in parentheses. 


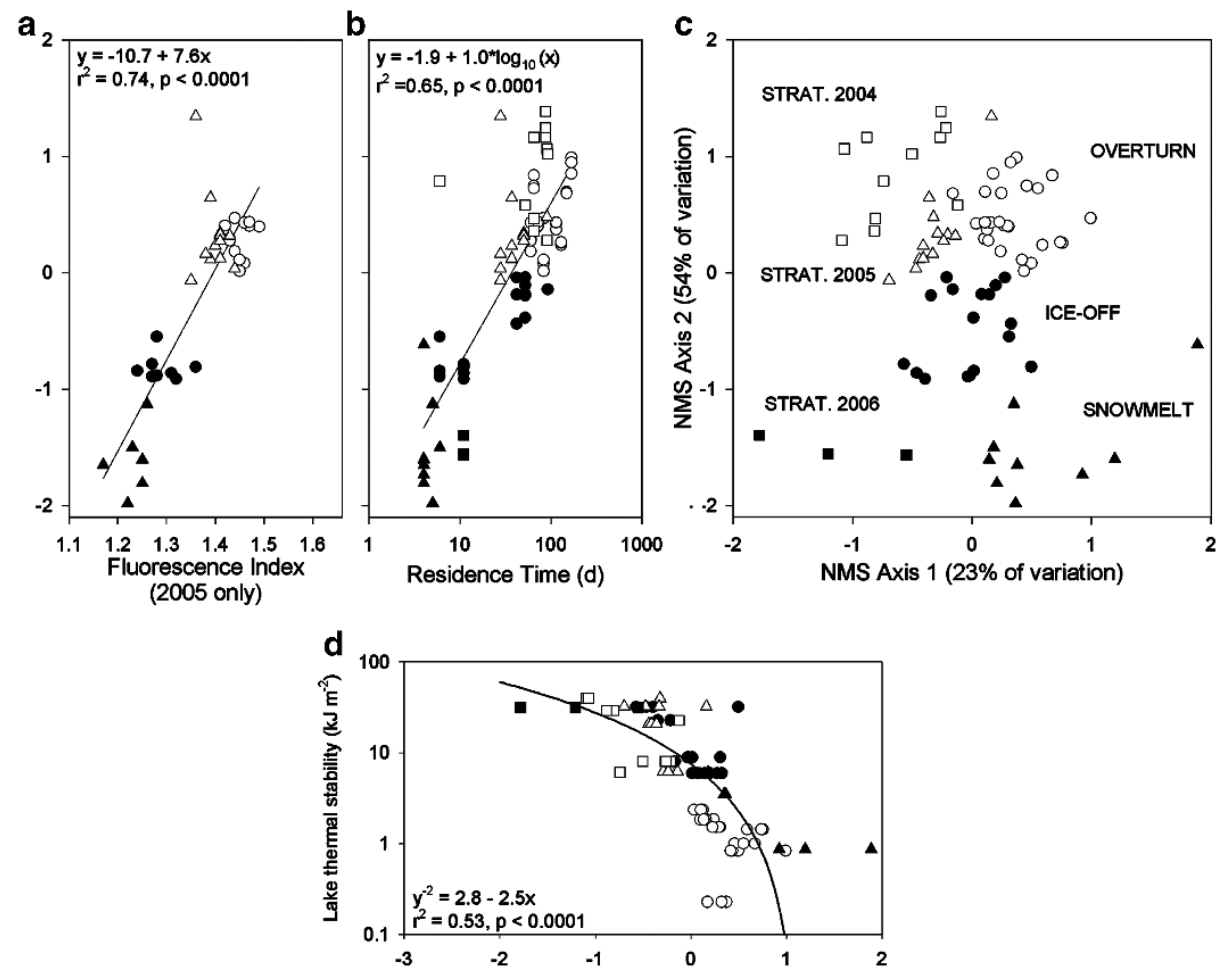

Figure 5 NMS ordination of lake TRFLP fingerprint samples in relation to environmental descriptors. (c) is the two-dimensional NMS solution with symbols coded according to groups defined in Figure 1 (final stress $=18.7$, cumulative $r^{2}$ between ordination distances and original distances $=0.77$, axes $99.2 \%$ orthogonal, $n=80$ ). Panels $(\mathbf{a}, \mathbf{b}$ and $\mathbf{d}$ ) display relationships between ordination axes and the strongest univariate independent variables for each. Note that increased FI values are associated with an increased relative contribution of autochthonous DOM. DOM, dissolved organic matter; FI, fluorescence index; NMS, nonmetric multidimensional scaling; TRFLP, terminal restriction fragment length polymorphism.

correlated with the relative abundances of Cyanobacteria and both Actinobacteria clades and negatively correlated with both clades of the $\beta$-Proteobacteria. Stepwise multiple regressions were used to determine the proportion of variation in the relative abundances of dominant clades explained by various environmental factors (Table 3). Coefficients of determination for the multivariate models ranged from 0.14 (Verrucomicrobia) to 0.84 (Methylophilales) with an average of 0.41 . Lake residence time and thermal stability were significantly related to the relative contribution of every clade, save the Burkholderiales and Cellulomonadaceae, both of which were related to nitrogen concentration and temperature. Temperature was also significantly related to the relative contributions of Sphingobacteria and Methylophilales. DOC was weakly but significantly related to Cyanobacterial relative abundance, and TP was significantly related to Flavobacteria relative abundance.

\section{Discussion}

Characterizing microbial phenology

The establishment of recurring interannual patterns in bacterioplankton communities highlighted here and elsewhere, as well as correlations between these patterns and physical and chemical variables, provides important new information on the description and possible drivers of microbial community structure (Morris et al., 2005; Fuhrman et al., 2006; Hullar et al., 2006; Kan et al., 2006; Martiny et al., 2006; Shade et al., 2007). As predictable phenological patterns have been observed widely in plant and animal communities, delineating such patterns in bacterioplankton communities lends support to the concept that general ecological principles may apply to both macro- and microorganisms. In one of the first studies providing a high-frequency, multiyear data set of bacterioplankton community composition, Morris et al. (2005) demonstrated that specific dominant phylotypes showed recurring population patterns associated with convective overturn and stratification at the Bermuda Atlantic Time Series station in the Sargasso Sea. More recently, Fuhrman et al. (2006) and Shade et al. (2007) used similar 6-year data sets to demonstrate consistent phenological patterns in bacterial communities in coastal and lake ecosystems, respectively, with both studies identifying a suite of physical, chemical and biological variables, including water temperature, mixing regime, nutrient availability and phytoplankton growth, which were correlated with bacterial community structure. The results of this study extend these findings, 
Table 2 Results of BIO-ENV algorithm comparing Sørensen dissimilarity matrix of lake TRFLP samples with multiple Euclidean distance matrices generated from all possible combinations of selected environmental variables

\section{Environmental variables}

Matrices generated from multiple variables

Residence time, thermal stability

Residence time, thermal stability, local temperature

Residence time, thermal stability, local temperature, DON

Residence time, thermal stability, local temperature,

DON, nitrate

Matrices generated from individual variables

DOM fluorescence index (only measured in 2005, $n=39$ ) 0.75

Residence time

0.64

Thermal stability

Local temperature

0.26

DON

Nitrate

PC

PN

DOC

TP

Abbreviations: DOC, dissolved organic carbon; DOM, dissolved organic matter; PC, particulate carbon; PN, particulate nitrogen; TRFLP, terminal restriction fragment length polymorphism.

With the exception of the DOM fluorescence index noted above, all depths and years were included in the analysis $(n=80)$. The correlation statistic $r$ may be interpreted as a stepwise Mantel test of correlation between the TRFLP Sørensen bacterial community distance matrix and a Euclidean distance matrix generated from the specified environmental variables.

demonstrating predictable seasonal patterns in both overall bacterioplankton community composition and the relative abundance dynamics of specific bacterial phylotypes, and relating each to interannual patterns of specific physical and chemical environmental variables.

The timing of limnetic transitions related to water-column stability and hydraulic residence time, which are in turn related to climatic conditions, is highly correlated with bacterioplankton phenology in Emerald Lake. Phytoplankton seasonality has been observed and studied extensively throughout the past century, and many studies in small dimictic lakes have categorized the emergence of predictable community types according to seasonal physical transitions similar to those defined for bacterioplankton phenology in this study (Sommer et al., 1986; Reynolds, 2006). In the ocean, the emergence of defined phytoplankton community types is broadly predictable in part based on interacting gradients of nutrient availability and mixing regime (Margalef, 1978; Smayda and Reynolds, 2001). These axes of physicochemical variability may be analogous to those observed in this study (residence time and thermal stability), suggesting that the phenology of both eukaryotic and bacterial microbial communities in pelagic ecosystems is regulated by similar processes. In Emerald

Lake, nutrient availability is strongly correlated with hydraulic residence time by two key nutrient delivery processes associated with snowmelt: the pulse of nitrate from catchment snowpack melting (for example, Sickman et al., 2003a) and the flushing of terrigenous DOM from catchment soils and vegetation (Boyer et al., 1997; Hood et al., 2005).

Linking DOM source to bacterial community structure The source and composition of the organic matter pool in aquatic environments has been shown repeatedly to be related to bacterial community structure and function (Cottrell and Kirchman, 2000; Covert and Moran, 2001; Carlson et al., 2002; Judd et al., 2006; Langenheder et al., 2006; Perez and Sommaruga, 2006; Kritzberg et al., 2006b). This study demonstrates a strong relationship between bacterioplankton community structure and seasonal shifts in the source of DOM (allochthonous vs autochthonous, measured by FI; Figure 5, Table 3). Crump et al. (2003) noted that shifts in bacterial community structure and production over 1 year in an Arctic lake were associated with the influx of terrestrially derived organic matter during snowmelt and a subsequent period of in situ production of DOM derived from phytoplankton. A suite of recent experimental studies examining the ability of DOM from different sources to alter the structure and function of the bacterioplankton community has demonstrated that communities generally shift to match DOM substrates from different sources across the landscape or among lakes (Judd et al., 2006; Kritzberg et al., 2006a), although these patterns are not consistent across all systems (Langenheder et al., 2005, 2006).

Recent experimental studies in high-elevation lakes have shown that the representation of Actinobacterial groups in bacterioplankton communities increases with the addition of terrigenous DOM and that bacterial communities become rapidly dominated by $\beta$-Proteobacteria with the addition of algal lysate (Perez and Sommaruga, 2006). In this study, correlations between FI and the relative abundances of Actinobacteria and $\beta$-Proteobacteria (Table 3), as well as temporal patterns in the relative abundances of both clones (Figure 6) and TRFLP peaks (Figure 7), suggest that Actinobacteria are a larger component of the bacterioplankton community when phytoplankton-derived organic matter is dominant, whereas $\beta$-Proteobacteria are dominant during snowmelt and ice-off when DOM is primarily derived from terrigenous sources. Although these results and those of Perez and Sommaruga (2006) appear to conflict, it is important to remember the limitations of relative abundance estimates and note that the same key bacterial groups were highlighted as responding to shifts in DOM composition and source in both studies. Moreover, the algal lysate enrichments employed by Perez and Sommaruga (2006) contained 10-fold more phosphorus than soil 


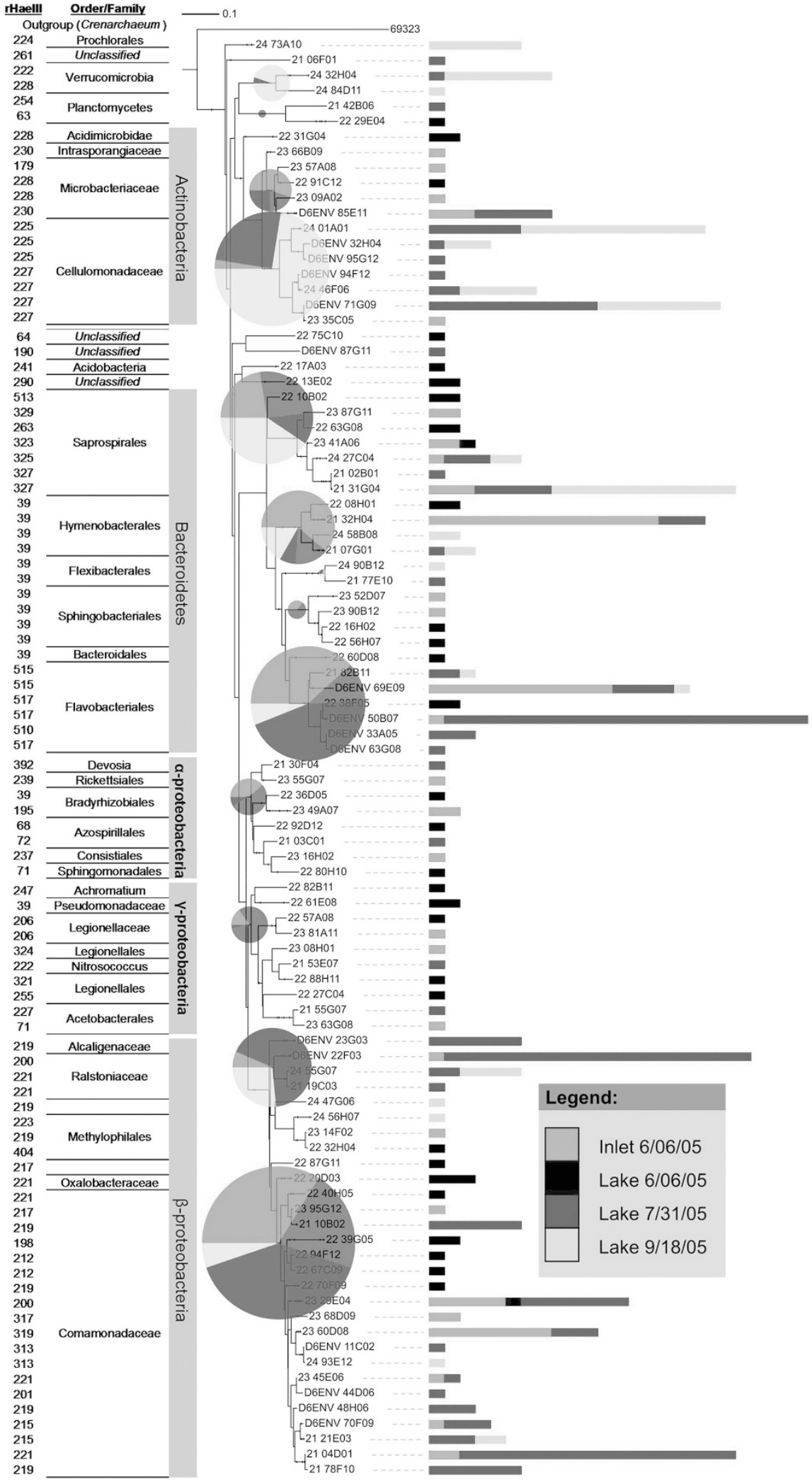

Figure 6 Phylogenetic tree of unique clones from Emerald Lake. Each clone is labeled with estimated terminal restriction length after in silico HaeIII digestion. Colored bars extending to the right of each clone ID represent the number of duplicate clones found in each environmental sample (scaled with the shortest bars equal to one clone). Pie charts centered at the base of dominant clades represent clone frequency distribution among the four sampled times in the lake: the size of the pie chart indicates the \% of total clones belonging to that clade, whereas the colors in the pie chart indicate the relative frequency of the clade in clone libraries from each of the four samples (for example, $\alpha$-Proteobacteria were a larger fraction of 6 June 2005 lake clones than 31 July 2005 lake clones). 


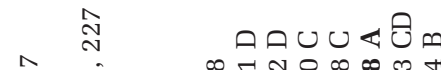

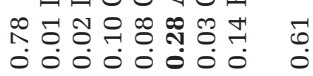

总要

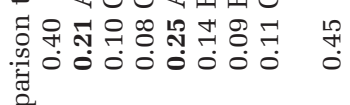

N द्व<smiles>C1CC2C3CC1CC2C3</smiles>
《ै

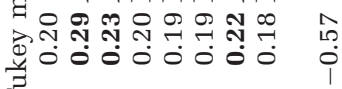

$$
\text { 芆 }
$$$$
\text { 刍 }
$$
द

$\stackrel{5}{5}$

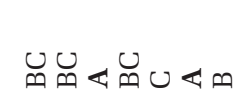

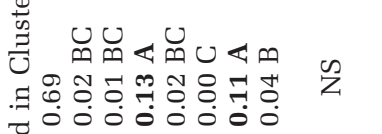
.

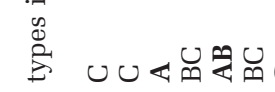

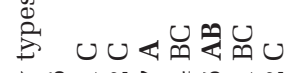

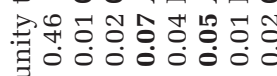$$
\text { 을 }
$$
站 青

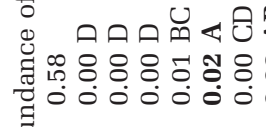
言

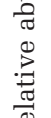




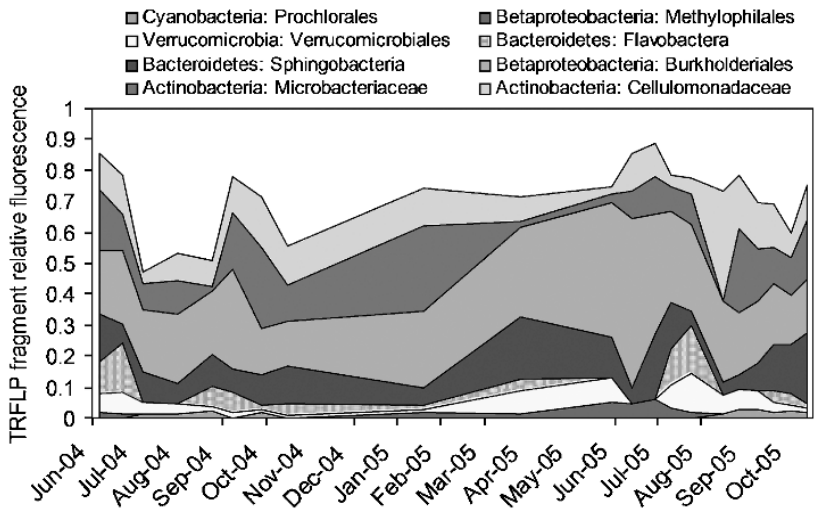

Figure 7 Temporal dynamics of dominant bacterioplankton clades at $2 \mathrm{~m}$ depth in Emerald Lake from June 2004 to October 2005. Each color represents the summed relative contribution of TRFLP peaks with fragment lengths belonging to a given phylogenetic clade to the total TRFLP peak area for samples collected at $2 \mathrm{~m}$ depth. TRFLP, terminal restriction fragment length polymorphism.

DOM enrichments. Experimental nutrient enrichment studies carried out in Emerald Lake have demonstrated that phosphorus enrichment tends to decrease the relative abundance of Actinobacteria and increase that of $\beta$-Proteobacteria, results akin to those of Perez and Sommaruga (2006), suggesting that nutrient enrichment and DOM source may interact to influence the relative abundances of these key groups (CE Nelson and CA Carlson, in review).

\section{Phenology of bacteria in high-elevation aquatic ecosystems}

In their seminal study of the population dynamics of bacterioplankton over a 1-year period in a highelevation alpine lake, Pernthaler et al. (1998) associated major shifts in the morphological and phylogenetic structure of bacterial communities with limnetic physical transitions, including iceoff, summer stratification and autumn overturn. In combination with a companion study conducted in the same lake (Glockner et al., 2000), their work demonstrated strong and predictable seasonal changes in the relative abundances of dominant bacterial groups (Actinobacteria, $\beta$-Proteobacteria and Bacteroidetes; aka CFB) similar to those detailed here for Emerald Lake. In both studies, a maximum in the relative abundance of the $\beta$-Proteobacteria was associated with snowmelt, ice-off and spring mixing, followed by a midsummer peak in Actinobacteria, with peaks in the relative abundances of the Bacteroidetes occurring during periods of mixing, including fall overturn and ice-off (Table 3). Further work has since demonstrated that the $\beta$-Proteobacteria and Actinobacteria constitute dominant proportions of the metabolically active bacterial community in high-elevation lakes (Perez and Sommaruga, 2006) with Actinobacteria adapted to high ultraviolet light levels (Warnecke et al., 2005) and both groups hypothesized to inhabit contrasting niches with respect to the seasonal availability of allochthonous material. Similarly, both groups were dominant members of the Emerald Lake community throughout the year, with their population dynamics linked to temporal variation in nitrate, DON, temperature and DOM source (Table 3), all factors associated with variation in snowmelt inputs.

Defining phenological changes in microbial communities is of prime importance because changes in microbial community structure are linked to shifts in fundamental ecosystem properties, including pelagic metabolism and organic matter export (for example, Carlson et al., 1998; Steinberg et al., 2001; Winder and Schindler, 2004; Morales-Baquero et al., 2006a). Recent climate shifts have led to an increasingly earlier onset of spring in the western United States, and some models predict that warming may lead to increasing variation in the magnitude and timing of winter precipitation in the mountainous regions (Beniston et al., 1997; Cayan et al., 2001). As this study encompassed disparate extremes of winter snowpack size and duration in the Sierra Nevada, these results highlight the significance of interannual climatic variation to the phenology of bacteria. In addition to demonstrating predictable prokaryotic phenology, recent work has contrasted temporal and spatial patterns of bacterioplankton community structure within morphologically complex lake basins, providing evidence that temporal patterns in bacterial community composition are related more to regional meteorologic patterns than to spatial environmental heterogeneity (Stepanauskas et al., 2003; Kan et al., 2006) and that unconnected aquatic ecosystems within the same region exhibit synchronous bacterial community dynamics (Crump and Hobbie, 2005; Kent et al., 2007). More evidence for the control of bacterial communities by regional climate processes may be found in linkages between the community structure of the bacterioplankton and that of the phytoplankton (Kent et al., 2004; Pinhassi et al., 2004).

\section{Stratification and bacterioplankton community differentiation}

Dissimilarity between bacterioplankton communities at different depths in Emerald Lake increased as thermal stratification increased, with increasing differences in communities separated by greater depth distances (Figure 4). Measurements of temperature profiles in Emerald Lake showed that thermal stability increases steadily during spring warming (Figures 3b and c), indicating that communities at different depths during this period experience extended periods of isolation. These results therefore lend support to the idea that microbial community differentiation scales with the duration and distance of physical isolation (Papke and Ward, 
2004). Summer lake stratification led to differences in bacterioplankton community types at different depths, as well as the emergence of communities that exhibited low interannual similarity (Figure 3). During stratified periods, including both summer and midwinter, TRFLP fingerprint patterns from the hypolimnion often clustered more closely with samples from adjacent dates and were generally distinct from epilimnetic samples.

Studies of temporal variation in bacterioplankton community structure in Wisconsin lakes have revealed similar patterns of decreased interannual similarity during summer stratification (Yannarell et al., 2003; Shade et al., 2007). During highly stratified periods, sporadic climatic events (for example, passing storms, wind-driven mixing, cloud cover) can have a larger impact on watercolumn density structure and concomitant biogeochemical dynamics than during mixed periods, with subsequent spatiotemporal resource heterogeneity possibly translating into unique environmental conditions that regulate the microbial community (MacIntyre et al., 2006). As microbial community dissimilarity increased with increasing distance of physical (depth) separation during stratified periods (Figure 4), these results suggest sensitive community responses to depth differences in environmental conditions, such as water temperature or light. Although not measured in this study, previous research in high-elevation lakes has emphasized the important function of solar radiation in structuring bacterial communities, with particular phylotypes adapted to the high flux of ultraviolet radiation found in shallow environments (Carrillo et al., 2002; Warnecke et al., 2005).

\section{Conclusions}

This study presents evidence that bacterioplankton community structure in high-elevation lakes exhibits predictable seasonal patterns across years. These phenological patterns are largely predictable from inter- and intraannual variation in snowmelt inputs and lake thermal stability, suggesting that the physicochemical factors (nutrient availability and mixing regime) driving bacterioplankton seasonality are similar to those understood to regulate phytoplankton community structure in both lakes and the oceans. However, multivariate models incorporating these variables explained less than half of the variation in the relative abundances of specific bacterial clades, suggesting that other factors have an important function in driving microbial population dynamics. In Emerald Lake, a headwater lake receiving primarily terrigenous snowmelt inputs and temporal variation in dissolved organic matter source was highly correlated with shifts in community composition and with the relative abundances of several dominant taxa, supporting the idea that variation in the composition of this heterogeneous resource may be an important driver of bacterio- plankton community dynamics. Bacterial communities in the lake exhibited greater variation throughout the water column during periods of increasing thermal stratification, suggesting that extended physical isolation and decreased community mixing may enhance phylogenetic differences in bacteria at different depths. Together, these results provide a clear framework for bacterioplankton phenology linked to regional meteorologic patterns, landscape processes and seasonal lake transitions, enhancing our understanding of how microbial communities respond to environmental factors at multiple scales.

\section{Acknowledgements}

I gratefully acknowledge Kevin Skeen for field assistance, J Jones for assistance with chlorophyll analysis, F Setaro for assistance with organic nutrient digestions, and $\mathrm{B}$ Clinton, A Engen and B Petty for conducting flowinjection and combustion elemental analysis. I am particularly indebted to JO Sickman and MA Anderson for their analysis of dissolved organic matter fluorescence. The comments of SD Cooper, CA Carlson and JM Melack greatly improved this paper. This study relied on the administrative support of Sequoia-Kings Canyon National Park and the UCSB Marine Science Institute. Financial support was provided by the University of California Water Resources Center Grant W988 to JM Melack and CA Carlson, NSF DDIG grant 0709975 to CE Nelson, and NSF grants 0089839 and 0614207 to JM Melack, JS Schimel and JO Sickman.

\section{References}

Beniston M, Diaz HF, Bradley RS. (1997). Climatic change at high elevation sites: an overview. Clim Change 36: 233-251.

Biddanda B, Ogdahl M, Cotner J. (2001). Dominance of bacterial metabolism in oligotrophic relative to eutrophic waters. Limnol Oceanogr 46: 730-739.

Boyer EW, Hornberger GM, Bencala KE, McKnight DM. (1997). Response characteristics of DOC flushing in an alpine catchment. Hydrol Process 11: 1635-1647.

Brown MV, Schwalbach MS, Hewson I, Fuhrman JA. (2005). Coupling 16S-ITS rDNA clone libraries and automated ribosomal intergenic spacer analysis to show marine microbial diversity: development and application to a time series. Environ Microbiol 7: 1466-1479.

Carlson CA, Ducklow HW, Hansell DA, Smith WO. (1998). Organic carbon partitioning during spring phytoplankton blooms in the Ross Sea polynya and the Sargasso Sea. Limnol Oceanogr 43: 375-386.

Carlson CA, Giovannoni SJ, Hansell DA, Goldberg SJ, Parsons R, Otero MP et al. (2002). Effect of nutrient amendments on bacterioplankton production, community structure, and DOC utilization in the northwestern Sargasso Sea. Aquat Microb Ecol 30: 19-36.

Carlson CA, Giovannoni SJ, Hansell DA, Goldberg SJ, Parsons R, Vergin K. (2004). Interactions among 
dissolved organic carbon, microbial processes, and community structure in the mesopelagic zone of the northwestern Sargasso Sea. Limnol Oceanogr 49: 1073-1083.

Carrera G, Fernandez P, Grimalt JO, Ventura M, Camarero L, Catalan J et al. (2002). Atmospheric deposition of organochlorine compounds to remote high mountain lakes of Europe. Environ Sci Technol 36: 2581-2588.

Carrillo P, Medina-Sanchez JM, Villar-Argaiz M. (2002). The interaction of phytoplankton and bacteria in a high mountain lake: Importance of the spectral composition of solar radiation. Limnol Oceanogr 47: 1294-1306.

Cayan DR, Kammerdiener SA, Dettinger MD, Caprio JM, Peterson DH. (2001). Changes in the onset of spring in the western United States. Bull Am Meteorol Soc 82: 399-415.

Chapin FS, Zavaleta ES, Eviner VT, Naylor RL, Vitousek PM, Reynolds HL et al. (2000). Consequences of changing biodiversity. Nature 405: 234-242.

Clarke KR, Ainsworth M. (1993). A method of linking multivariate community structure to environmental variables. Mar Ecol Prog Ser 92: 205-219.

Conrad R. (1996). Soil microorganisms as controllers of atmospheric trace gases (H2, CO, CH4, OCS, N2O, and NO). Microbiol Rev 60: 609-640.

Cotner JB, Ammerman JW, Peele ER, Bentzen E. (1997). Phosphorus-limited bacterioplankton growth in the Sargasso Sea. Aquat Microb Ecol 13: 141-149.

Cotner JB, Biddanda BA. (2002). Small players, large role: microbial influence on biogeochemical processes in pelagic aquatic ecosystems. Ecosystems 5: 105-121.

Cottrell MT, Kirchman DL. (2000). Natural assemblages of marine proteobacteria and members of the CytophagaFlavobacter cluster consuming low- and high-molecular-weight dissolved organic matter. Appl Environ Microbiol 66: 1692-1697.

Covert JS, Moran MA. (2001). Molecular characterization of estuarine bacterial communities that use high- and low-molecular weight fractions of dissolved organic carbon. Aquat Microb Ecol 25: 127-139.

Crump BC, Hobbie JE. (2005). Synchrony and seasonality in bacterioplankton communities of two temperate rivers. Limnol Oceanogr 50: 1718-1729.

Crump BC, Kling GW, Bahr M, Hobbie JE. (2003). Bacterioplankton community shifts in an arctic lake correlate with seasonal changes in organic matter source. Appl Environ Microbiol 69: 2253-2268.

Curtis TP, Sloan WT. (2004). Prokaryotic diversity and its limits: microbial community structure in nature and implications for microbial ecology. Curr Opin Microbiol 7: 221-226.

DeSantis TZ, Hugenholtz P, Keller K, Brodie EL, Larsen N, Piceno YM et al. (2006a). NAST: a multiple sequence alignment server for comparative analysis of $16 \mathrm{~S}$ rRNA genes. Nucleic Acids Res 34: W394-W399.

DeSantis TZ, Hugenholtz P, Larsen N, Rojas M, Brodie EL, Keller K et al. (2006b). Greengenes, a chimera-checked 16S rRNA gene database and workbench compatible with ARB. Appl Environ Microbiol 72: 5069-5072.

Felsenstein J. (2005). PHYLIP (Phylogeny Inference Package). Distributed by the author. Department of Genome Sciences, University of Washington, Seattle, WA, USA.

Fenn ME, Baron JS, Allen EB, Rueth HM, Nydick KR, Geiser L et al. (2003). Ecological effects of nitrogen deposition in the western United States. Bioscience 53: $404-420$.
Finlay BJ. (2002). Global dispersal of free-living microbial eukaryote species. Science 296: 1061-1063.

Fuhrman JA, Hewson I, Schwalbach MS, Steele JA, Brown MV, Naeem S. (2006). Annually reoccurring bacterial communities are predictable from ocean conditions. Proc Natl Acad Sci USA 103: 13104-13109.

Fuhrman JA, Sleeter TD, Carlson CA, Proctor LM. (1989). Dominance of bacterial biomass in the Sargasso Sea and its ecological implications. Mar Ecol Prog Ser 57: 207-217.

Glockner FO, Zaichikov E, Belkova N, Denissova L, Pernthaler J, Pernthaler A et al. (2000). Comparative 16S rRNA analysis of lake bacterioplankton reveals globally distributed phylogenetic clusters including an abundant group of actinobacteria. Appl Environ Microbiol 66: 5053-5065.

Grant A, Ogilvie LA. (2004). Name that microbe: rapid identification of taxa responsible for individual fragments in fingerprints of microbial community structure. Mol Ecol Notes 4: 133-136.

Hall TA. (1999). BioEdit: a user-friendly biological sequence alignment editor and analysis program for Windows 95/98/NT. Nucl Acids Symp Ser 41: 95-98.

Haukka K, Kolmonen E, Hyder R, Hietala J, Vakkilainen K, Kairesalo $\mathrm{T}$ et al. (2006). Effect of nutrient loading on bacterioplankton community composition in lake mesocosms. Microb Ecol 51: 137-146.

Hewson I, Fuhrman JA. (2006). Improved strategy for comparing microbial assemblage fingerprints. Microb Ecol 51: 147-153.

Hood E, McKnight DM, Williams MW. (2003). Sources and chemical character of dissolved organic carbon across an alpine/subalpine ecotone, Green Lakes Valley, Colorado Front Range, United States. Water Resour Res 39: 1188-1199.

Hood E, Williams MW, McKnight DM. (2005). Sources of dissolved organic matter (DOM) in a Rocky Mountain stream using chemical fractionation and stable isotopes. Biogeochemistry 74: 231-255.

Huber T, Faulkner G, Hugenholtz P. (2004). Bellerophon: a program to detect chimeric sequences in multiple sequence alignments. Bioinformatics 20: 2317-2319.

Hullar MAJ, Kaplan LA, Stahl DA. (2006). Recurring seasonal dynamics of microbial communities in stream habitats. Appl Environ Microbiol 72: 713-722.

Idso SB. (1973). On the concept of lake stability. Limnol Oceanogr 18: 681-683.

Judd KE, Crump BC, Kling GW. (2006). Variation in dissolved organic matter controls bacterial production and community composition. Ecology 87: 2068-2079.

Kan JJ, Crump BC, Wang K, Chen F. (2006). Bacterioplankton community in Chesapeake Bay: predictable or random assemblages. Limnol Oceanogr 51: 2157-2169.

Kent AD, Jones SE, Yannarell AC, Graham JM, Lauster GH, Kratz TK et al. (2004). Annual patterns in bacterioplankton community variability in a humic lake. Microb Ecol 48: 550-560.

Kent AD, Yannarell AC, Rusak JA, Triplett EW, McMahon KD. (2007). Synchrony in aquatic microbial community dynamics. ISME J 1: 38-47.

Kritzberg ES, Cole JJ, Pace MM, Graneli W. (2006a). Bacterial growth on allochthonous carbon in humic and nutrient-enriched lakes: results from whole-lake C-13 addition experiments. Ecosystems 9: 489-499.

Kritzberg ES, Langenheder S, Lindstrom ES. (2006b). Influence of dissolved organic matter source on lake 
bacterioplankton structure and function-implications for seasonal dynamics of community composition. FEMS Microbiol Ecol 56: 406-417.

Langenheder S, Lindstrom ES, Tranvik LJ. (2005). Weak coupling between community composition and functioning of aquatic bacteria. Limnol Oceanogr 50: 957-967.

Langenheder S, Lindstrom ES, Tranvik LJ. (2006). Structure and function of bacterial communities emerging from different sources under identical conditions. Appl Environ Microbiol 72: 212-220.

Letunic I, Bork P. (2007). Interactive Tree Of Life (iTOL): an online tool for phylogenetic tree display and annotation. Bioinformatics 23: 127-128.

Lindstrom ES. (1998). Bacterioplankton community composition in a boreal forest lake. FEMS Microbiol Ecol 27: 163-174.

Liu WT, Marsh TL, Cheng H, Forney LJ. (1997). Characterization of microbial diversity by determining terminal restriction fragment length polymorphisms of genes encoding 16S rRNA. Appl Environ Microbiol 63: $4516-4522$.

MacIntyre S, Sickman JO, Goldthwait SA, Kling GW. (2006). Physical pathways of nutrient supply in a small, ultraoligotrophic arctic lake during summer stratification. Limnol Oceanogr 51: 1107-1124.

Margalef R. (1978). Life-forms of phytoplankton as survival alternatives in an unstable environment. Oceanol Acta 1: 493-509.

Martiny JBH, Bohannan BJM, Brown JH, Colwell RK, Fuhrman JA, Green JL et al. (2006). Microbial biogeography: putting microorganisms on the map. Nat Rev Microbiol 4: 102-112.

McCune B, Mefford MJ. (2006). PC-ORD v5. Multivariate Analysis of Ecological Data. MJM Software Design, Gleneden Beach, OR, USA.

McKnight DM, Boyer EW, Westerhoff PK, Doran PT, Kulbe T, Andersen DT. (2001). Spectrofluorometric characterization of dissolved organic matter for indication of precursor organic material and aromaticity. Limnol Oceanogr 46: 38-48.

Melack JM, Dozier J, Goldman CR, Greenland D, Milner AM, Naiman RJ. (1997). Effects of climate change on inland waters of the Pacific Coastal Mountains and Western Great Basin of North America. Hydrol Process 11: 971-992.

Melack JM, Stoddard JL. (1991). Sierra Nevada. In: Charles DF (ed), Acidic Deposition and Aquatic Ecosystems: Case Studies. New York: Springer-Verlag, pp 503-530.

Morales-Baquero R, Carrillo P, Barea-Arco J, Perez-Martinez C, Villar-Argaiz M. (2006a). Climate-driven changes on phytoplankton-zooplankton coupling and nutrient availability in high mountain lakes of Southern Europe. Freshw Biol 51: 989-998.

Morales-Baquero R, Pulido-Villena E, Reche I. (2006b). Atmospheric inputs of phosphorus and nitrogen to the southwest Mediterranean region: biogeochemical responses of high mountain lakes. Limnol Oceanogr 51: 830-837.

Morris RM, Vergin KL, Cho JC, Rappe MS, Carlson CA, Giovannoni SJ. (2005). Temporal and spatial response of bacterioplankton lineages to annual convective overturn at the bermuda atlantic time-series study site. Limnol Oceanogr 50: 1687-1696.

Ochman H, Lawrence JG, Groisman EA. (2000). Lateral gene transfer and the nature of bacterial innovation. Nature 405: 299-304.
Papke RT, Ward DM. (2004). The importance of physical isolation to microbial diversification. FEMS Microbiol Ecol 48: 293-303.

Perez MT, Sommaruga R. (2006). Differential effect of algal- and soil-derived dissolved organic matter on alpine lake bacterial community composition and activity. Limnol Oceanogr 51: 2527-2537.

Pernthaler J, Glockner FO, Unterholzner S, Alfreider A, Psenner R, Amann R. (1998). Seasonal community and population dynamics of pelagic bacteria and archaea in a high mountain lake. Appl Environ Microbiol 64: 4299-4306.

Pinhassi J, Sala MM, Havskum H, Peters F, Guadayol O, Malits A et al. (2004). Changes in bacterioplankton composition under different phytoplankton regimens. Appl Environ Microbiol 70: 6753-6766.

Prosser JI, Bohannan BJM, Curtis TP, Ellis RJ, Firestone MK, Freckleton RP et al. (2007). Essay-The role of ecological theory in microbial ecology. Nat Rev Microbiol 5: 384-392.

Psenner R. (1999). Living in a dusty world: Airborne dust as a key factor for alpine lakes. Water Air Soil Pollut 112: $217-227$.

Reynolds CS. (2006). Ecology of Phytoplankton. New York: Cambridge University Press.

SAS-Institute (2007). JMP. SAS Institute: Cary, NC.

Schmidt W. (1928). Über die Temperatur- und Stabilitätsverhältnisse von Seen. Geografiska Annaler 10: 145-177.

Shade A, Kent AD, Jones SE, Newton RJ, Triplett EW, McMahon KD. (2007). Interannual dynamics and phenology of bacterial communities in a eutrophic lake. Limnol Oceanogr 52: 487-494.

Sickman JO, Leydecker A, Chang CCY, Kendall C, Melack JM, Lucero DM et al. (2003a). Mechanisms underlying export of $\mathrm{N}$ from high-elevation catchments during seasonal transitions. Biogeochemistry 64: 1-24.

Sickman JO, Melack JM, Clow DW. (2003b). Evidence for nutrient enrichment of high-elevation lakes in the Sierra Nevada, California. Limnol Oceanogr 48: 1885-1892.

Smayda TJ, Reynolds CS. (2001). Community assembly in marine phytoplankton: application of recent models to harmful dinoflagellate blooms. J Plankton Res 23: 447-461.

Smith RC, Bakers KS, Dustan P. (1981). Fluorometric techniques for the measurement of oceanic chlorophyll in the support of remote sensing. Ref Rep Scripps Institution of Oceanography (La Jolla, California) 81-17: 1-14.

Sommer U, Gliwicz ZM, Lampert W, Duncan A. (1986). The PEG-model of seasonal succession of planktonic events in fresh waters. Arch Hydrobiol 106: 433-471.

Sørensen TJ. (1948). A method of establishing groups of equal amplitude in plant sociology based on similarity of species content and its application to analysis of the vegetation of the Danish Commons. Biologiske Skrifter 5: $1-34$.

Steinberg DK, Carlson CA, Bates NR, Johnson RJ, Michaels AF, Knap AH. (2001). Overview of the US JGOFS Bermuda Atlantic Time-series Study (BATS): a decade-scale look at ocean biology and biogeochemistry Deep Sea Res Part II Top Stud Oceanogr 48: 1405-1447.

Stepanauskas R, Moran MA, Bergamaschi BA, Hollibaugh JT. (2003). Covariance of bacterioplankton composition 
and environmental variables in a temperate delta system. Aquat Microb Ecol 31: 85-98.

Stothard P. (2000). The sequence manipulation suite: JavaScript programs for analyzing and formatting protein and DNA sequences. Biotechniques 28: 1102-1104.

Valderrama JC. (1981). The simultaneous analysis of total nitrogen and total phosphorus in natural waters. Mar Chem 10: 109-122.

Walther GR, Post E, Convey P, Menzel A, Parmesan C, Beebee TJC et al. (2002). Ecological responses to recent climate change. Nature 416: 389-395.

Warnecke F, Sommaruga R, Sekar R, Hofer JS, Pernthaler J. (2005). Abundances, identity, and growth state of actinobacteria in mountain lakes of different UV transparency. Appl Environ Microbiol 71: 5551-5559.
Winder M, Schindler DE. (2004). Climatic effects on the phenology of lake processes. Glob Chang Biol 10: 1844-1856.

Yannarell AC, Kent AD, Lauster GH, Kratz TK, Triplett EW. (2003). Temporal patterns in bacterial communities in three temperate lakes of different trophic status. Microb Ecol 46: 391-405.

Yannarell AC, Triplett EW. (2005). Geographic and environmental sources of variation in lake bacterial community composition. Appl Environ Microbiol 71: 227-239.

Yu YN, Breitbart M, McNairnie P, Rohwer F. (2006). FastGroupII: A web-based bioinformatics platform for analyses of large 16S rDNA libraries. BMC Bioinformatics 7: 57-65.

Supplementary Information accompanies the paper on The ISME Journal website (http://www.nature.com/ismej) 